\title{
Belarus: Higher Education Dynamics and Institutional Landscape
}

\section{Olga Gille-Belova and Larissa Titarenko}

The HE system in Belarus has undergone important changes since the beginning of the 1990s under the pressure of various internal and external factors (including demographic, political, socio-economic changes and international cooperation). A study of changes in the HE system in the Republic of Belarus during the post-Soviet period can be made by using an analytical framework based on the conceptual distinction between three types of higher education system characteristics: horizontal diversification, vertical differentiation and organisational interrelationship (Teichler 1988). We will focus on these three dimensions in our analysis of main changes in the institutional landscape of Belarusian HE and discuss the issue of its diversity "as being about both similarities and differences" (Huisman et al. 2007, 565).

O. Gille-Belova

Department of Slavic Studies, University Bordeaux Montaigne, Bordeaux, France

L. Titarenko $(\bowtie)$

Department of Sociology, Belarusian State University, Minsk, Republic of Belarus

(C) The Author(s) 2018

J. Huisman et al. (eds.), 25 Years of Transformations of Higher

Education Systems in Post-Soviet Countries, Palgrave Studies in Global

Higher Education, https://doi.org/10.1007/978-3-319-52980-6_5 
Horizontal system diversification increased with the creation of new private and public HEIs, and changes in the functioning of the former Soviet HEIs. The vertical system differentiation inherited from the Soviet period was slightly changed by the end of the 1990s/beginning of the 2000s. It was strengthened, especially at the beginning of 2010, as a result of government policies (Educational Code 2011) and the introduction of national, regional and international rankings that made the existing vertical diversity more visible. The organisational interrelationship between HEIs has also changed from the logic of complementarity under the Soviet system to the logic of competition for students and resources.

This chapter will first analyse the HE system inherited from the Soviet period, because Soviet legacies still play an extremely important role in the Belarusian case. Then it will explore the main factors influencing the transformations in the HE landscape over more than 20 years. Finally, it will present the typology of existing Belarusian HEIs. The conclusion will draw some inferences about the further evolution of the national higher education system.

\section{The He System Within the Soviet Context}

If some Soviet republics inherited universities from the pre-Soviet period founded according to the German "Humboldt model" (Universities of Moscow, St. Petersburg, Kiev), it was not the case in Belarus. Under Russian Empire rule, only few secondary level establishments existed in this region (gymnasiums, vocational and parish schools), and three teachers' institutes were founded in Vitebsk in 1910, in Mogilev in 1913 and in Minsk in 1914. The HE system in Belarus was built from scratch during the Soviet period after the establishment of the Byelorussian ${ }^{1}$ Soviet Socialist Republic (BSSR) in January 1919. This system was designed as a part of a larger Soviet "master plan". ${ }^{2}$ From the beginning, it was intended as a vocational institutional structure with the main mission to train professionals for the needs of the Soviet command economy in the Byelorussian Republic. The main functions of the HE system included: (1) professional training for the needs of the national economy (according to the branches of the national economy in the BSSR); (2) reproduction of the Soviet managerial elite at all levels for the republic; and (3) Soviet ideological education for the younger generation. 
The first university in Belarus was opened in the newly established republic in 1921. This university (Byelorussian State University, or BSU) was designed as the only one for the whole republic and it was a multidisciplinary comprehensive establishment with the main mission to train staff $^{3}$ for future BSSR HEIs and research institutes, as well as managers for the republic administration. Other HEIs were actively founded in the 1920-1930s, mainly as specialised institutes (instituty) to prepare cadres for particular sectors such as social infrastructure and economic development for the republic (teachers, doctors, economists, engineers). By 1940-1941, the BSSR had 25 HEIs with 21,500 students and 927 staff at different levels (Krasovskii 1972). Some of these institutes were transformed from the former BSU faculties: the Medical Institute (BSMI $)^{4}$ in 1930, Minsk State Pedagogical Institute $(\mathrm{MSPI})^{5}$ in 1931 and the Byelorussian Institute of National Economy $(B I N E)^{6}$ in 1933. The other institutes were built by upgrading secondary level vocational establishments (for example, Byelorussian Polytechnic Institute, BPI, ${ }^{7}$ was transformed in 1920 from Minsk Polytechnic College) or regional pedagogical institutes transformed from former pedagogical colleges. Vertical differentiation selected five major establishments (BSU, BPI, MSPI, Medical Institute and BINE) as the core of the Byelorussian HE system; they performed the leading methodological functions for others and covered the training needs for main branches of republic professionals.

In the post-World War II period, expansion in the horizontal differentiation of the HE system continued: in 1958-1959 there were 56,700 students with more than 3,000 professorial teaching staff in 25 HEIs (Yearbook 1959). In order to develop the HE system in the regional (oblast) centres and introduce more balance, two new universities were opened, one in Gomel in 1969 and another in Grodno in 1972, on the foundations of existing pedagogical institutes. The separation of some faculties at Minsk State Pedagogical Institute gave birth to the Minsk State Pedagogical Institute of Foreign Languages ${ }^{8}$ in 1948 and the Institute of Culture $^{9}$ in 1975. Some new stand-alone specialised industrial HE institutes were also founded. These included Minsk Radio Technical Institute $(\mathrm{RTI})^{10}$ in 1964 , the Institute of Mechanization and Electrification of Agriculture $^{11}$ in 1954 and Belarusian Technological Institute, ${ }^{12}$ which was reorganised from the Forest Technical Institute in 1961. Growth in the HE system mainly met new economic needs and was connected with labour market demands for new plants and factories; it also supported the 
development of agriculture, chemical and electronic industries and mechanical constructions.

Several institutes were opened in the regional centres: Mogilev Machine Building Institute ${ }^{13}$ (1961) trained cadres for the Mogilev elevators plant (one of the biggest in Eastern Europe), and the Belarusian Institute of Railway Engineers ${ }^{14}$ (1953) in Gomel prepared specialists for the transport sector. Other specialised regional institutes included Vitebsk Technological Institute of Light Industry ${ }^{15}$ (1965) and Grodno State Medical Institute ${ }^{16}$ (1958). Preparation of managerial personnel and professional ideological training were conducted by Minsk Higher Communist Party School in 1958. As everywhere in the USSR, it performed the important functions of reproducing the political elite and handling the regular ideological training of Soviet personnel with various educational backgrounds.

By the end of the Soviet period, the BSSR had 33 HEIs with 188,600 students and 15,400 staff including professors. BSU dominated the system as the oldest republican comprehensive university, followed by the main specialised republican institutes situated in Minsk. Outside Minsk, all administrative regional centres had either their own university (Grodno, Gomel) or pedagogical institute (Vitebsk, Brest, Mogilev); in some cases, this meant specialised institutes to train employees for a particular factory or meet other regional needs for society and the national economy (see Table 5.1). Like the universities, major specialised institutes and pedagogical institutes generally depended on the Ministry of Education of BSSR, while narrowly specialised institutes were under the control of the corresponding BSSR ministries. This vertical differentiation included general supervision by Soviet Union ministries in the relevant field from Moscow.

The increasing number of HEIs and staff during the Soviet period reflected the fast growth of young Soviet Byelorussians graduating from secondary schools with educational expectations that met the increasing needs of the national economy for professionals and well-trained personnel in the BSSR. In the last two to three Soviet decades, the BSSR was recognised as a manufacturing and industrial centre of the Soviet Union; therefore, all professionals for the factories and plants situated in the BSSR were trained mainly in the republic. As the republic was highly industrialised, most of its HEIs were oriented toward industry or other practical needs of the national economy including training for doctors, teachers, economists, and agronomists. Only the universities provided a limited space for education that was not directly connected with local needs (in philosophy, psychology, and sociology); therefore, young people had to move to other cities for education in fields not represented in Belarus. 


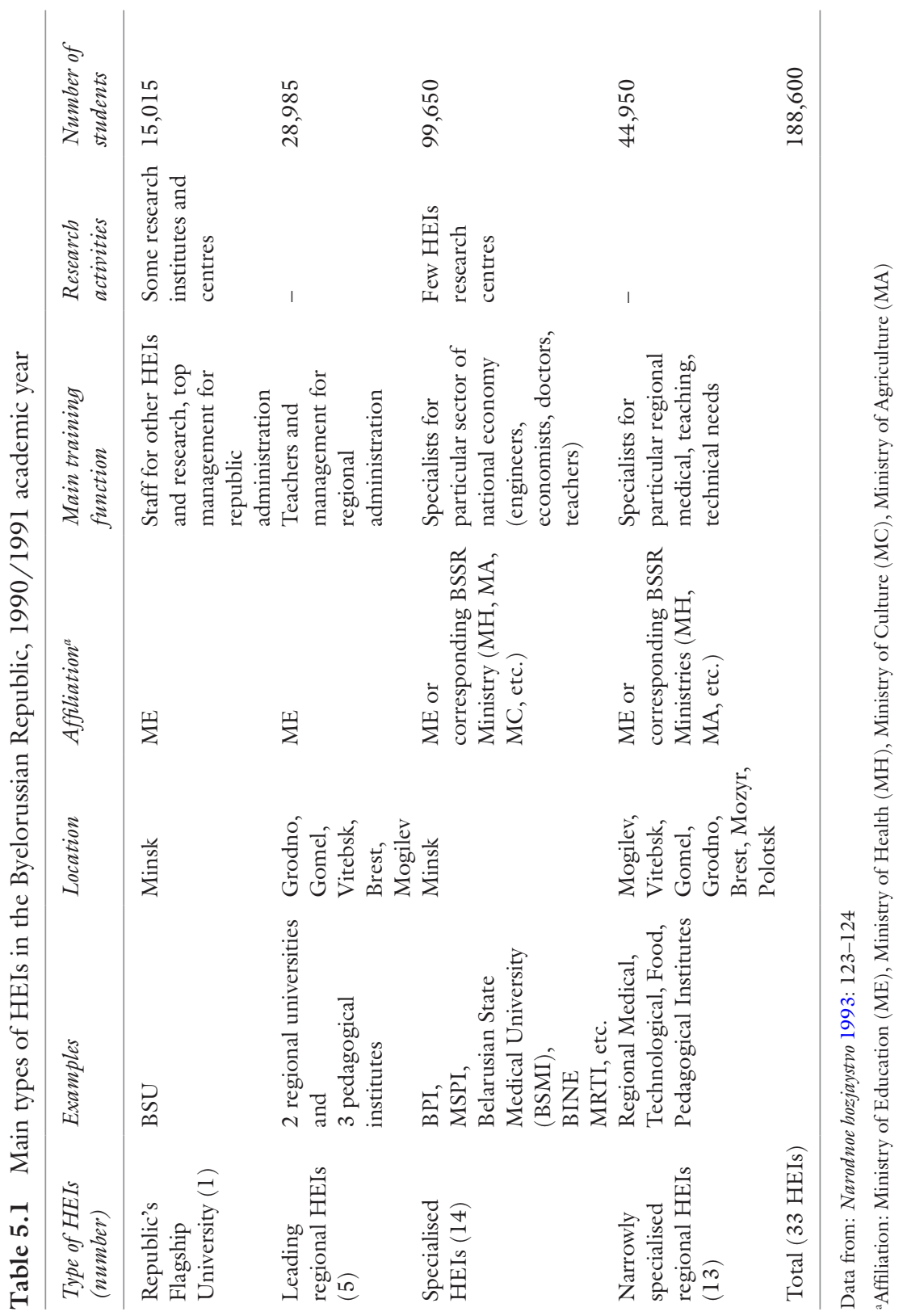


Few Byelorussian HEIs had their own research centres and the level of financial support provided for research activities was rather low.

As for internationalisation, in 1988-1989 there were officially 6,800 (3.8\%) foreign students in the BSSR (including military students) (Vetokhin 2001, 91). They arrived mainly from African and Asian countries that formally followed the Marxist ideology and were therefore supported by the USSR authorities. Such exchange was part of the internationalisation activities conceived on the all-Union level in order to reinforce the ties between the USSR and its closest allies. Most foreign students studied for free and paid only for their living expenses.

In conclusion, Byelorussian HE existed in 1991 as a "Soviet legacy" based mainly on complementary interrelationships between HEIs, each designed to respond to the particular economic or social needs of the republic or the region. However, this system was designed for the out-ofdate challenges of the Soviet political and industrial economic model, which led to requests for important reforms at the beginning of 1990 .

\section{Changes in the Higher Education System in Post- Soviet Belarus: Slow Evolution Under State Control}

The end of the USSR and the formation of the new independent state, the Republic of Belarus, in 1991 marked the beginning of a long period of political, economic and social transformations in the country, which had an important impact on the HE system. In Belarus, like everywhere in post-Socialist states, ideas such as "democratisation" "decentralisation" "liberalisation" "pluralism" and "humanisation of learning" became very popular at the beginning of 1990 in regard to transformations in the field of education (Silova 2009, 296) and construction of the nation-state; some new liberal ideas coexisted with attempts by the ministerial authorities to preserve the "best practices" of the former Soviet system (Vetokhin 2001 ). It was particularly the new Law on Education (adopted by parliament on 29 October 1991) that played an important role in the transformation of the system inherited from the Soviet period. ${ }^{17}$ It authorised the creation of private HEIs and the introduction of fees in state-owned public HEIs, granted more freedom in choosing programmes and disciplines offered by each HEI and replaced the nomination of university rectors with elections. Additionally, new specialties needed for the nation-state 
were introduced in new faculties at existing HEIs, such as "diplomacy" at the BSU Faculty of International Relations, and customs service at BSU and Belarusian National Technical University (BNTU). Despite these important changes in the legislative framework, Belarusian authorities had no clear ambition to create a radically new HE model; instead, they tried to adapt the former Soviet model to a new political, economic, social and international reality (Gille-Belova 2014).

This new legislative framework had an important impact on the HE system in breaking the state monopoly on education and stimulating system diversification. During the 1990s, many academic actors created new private HEIs or transformed existing public HEIs by creating new faculties and introducing new programmes. Ministry of Education officials did not have any particular "master plan" to guide the institutional changes, but they followed this spontaneous process. Their role was limited to the general supervision of the diversification process, mainly financed by Belarusian students and their families: in fact, students at not only private HEIs paid fees, but almost two-thirds of the students in public HEIs also paid ${ }^{18}$ (NSCRB 2013, 147). Only one-third of students enjoyed public financial support provided by the Belarusian Ministry of Education in public HEIs (the limited number of state financed student places, mainly in "old traditional" fields of study, was fixed). In contrast, very few diplomas in the new fields (humanities, social sciences, management) were financed from the public budget, and therefore most students in these fields paid for their education. Within 20 years, the Belarusian state thus reduced its HE expenditure from $1 \%$ to $0.7 \%$ of GDP (IBK 2013, 20-22), despite the growing number of HEIs and students.

Horizontal diversification of $\mathrm{HE}$ during the 1990s-2000s was largely facilitated by demographic factors and corresponded to the massification of $\mathrm{HE}$, which happened between the mid-1990s and the beginning of the 2010s. New HEIs were founded and new faculties opened in existing HEIs with a huge range of new programmes due to the growing number of students. In the academic year 1989-1990, the number of students was almost 190,000 . It had increased to 250,000 by the end of the 1990 s and almost doubled during the 2000s, reaching its peak at 445,000 in 2011-2012 (see Fig. 5.1).

New private HEIs started to appear from 1994 and the number of HEIs almost doubled in a few years, increasing from 33 in 1990-1991 to 59 in 1995-1996. This was largely because of private sector growth; there were 20 private HEIs by 1996/97 (see Fig. 5.2). Leading members of the teaching staff at main public HEIs were generally the founders of new 


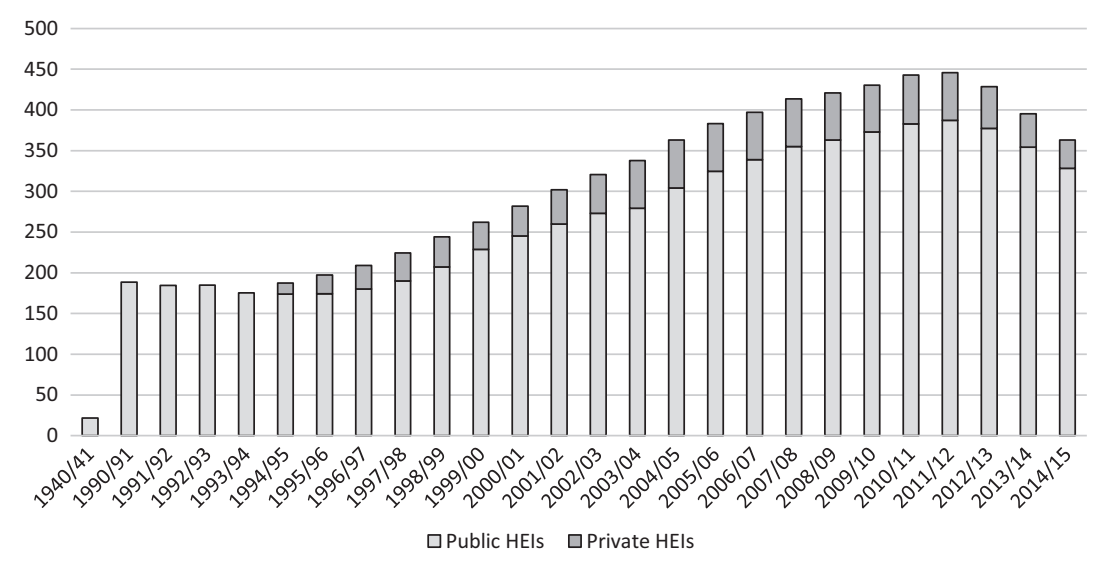

Fig. 5.1 Change in the number of HEI students in Belarus (thousands), 1940-2015 (Source: MORB 2001, 2013b; NSCRB 2013, 2014, 2015)

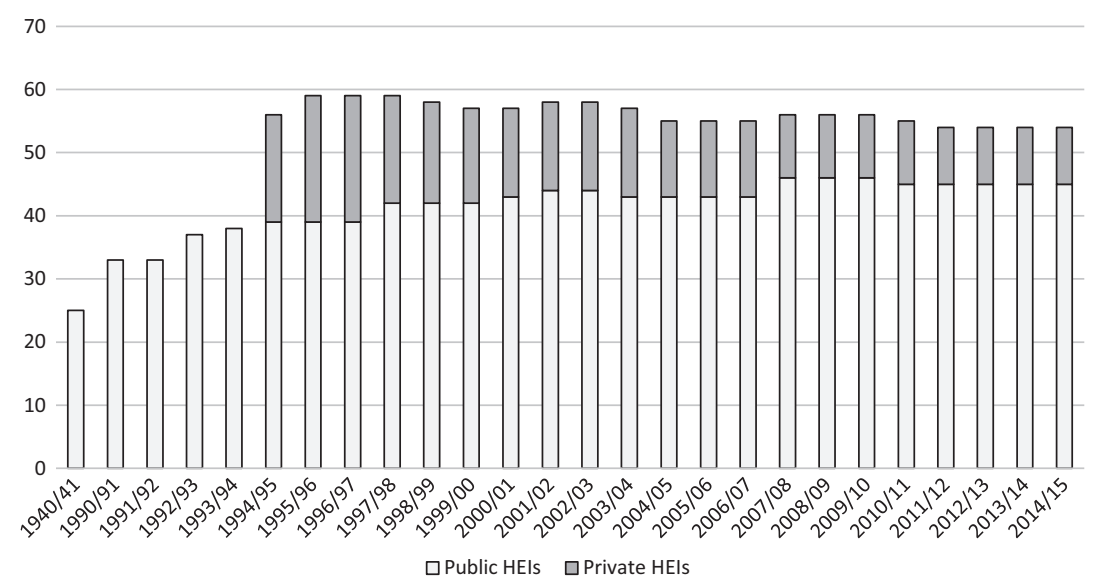

Fig. 5.2 Change in the number of HEIs in Belarus, 1940-2015 (Source: MORB 2001, 2013a; NSCRB 2013, 2014, 2015)

private HEIs, the staff of which was composed of part-time employees with full positions in nearby public HEIs. The number of students enrolled in private HEIs remained rather small and equal to about one-tenth of total student numbers (see Fig. 5.1). Private HEIs had a high proportion 
of part-time students ( $80 \%)$ that was much higher than in public HEIs (under $50 \%$ ) by the end of the 2000s. ${ }^{19}$ Most private HEIs were oriented toward training students in newly popular fields of study that represented a flux in education demands (management, economy, law and humanities). The disciplinary diversity in private HEIs was much more limited than in public HEIs, and competition between university enrolees was much lower than in public HEIs; tuition fees were generally lower as well.

The number of public HEIs did not increase until the end of 1990; most underwent significant changes by proposing new specialties and opening new faculties. Many public HEIs (in particular, the narrowly specialised ones) created so-called "non-profile" faculties of management and economics or humanities during the Soviet period. Their motivation was mainly financial, as all students of these new faculties paid relatively high fees while the demand for the traditional "profile" fields of study (engineers, agronomists, teachers) was less important and financed mainly by the state. ${ }^{20}$ As state finances decreased during the economic crisis at the beginning of the 1990s, student fees became an important source of complementary revenue for public HEIs. At the same time, most of the former public HEIs called "institutes" were transformed into universities or academies. This ministry policy of "relabelling" responded to HEIs' leadership desire for higher symbolic recognition and prestige. These changes contributed to vertical and new horizontal differentiation.

Government policies started to change during the 2000s; as a result, the attitudes of Ministry of Education officials reoriented from supervision of a largely spontaneous HE system diversification to tighter control. The main reason for these changes was political, and related to the logic of consolidation by the authoritarian political regime searching to strengthen its ideological control over $\mathrm{HE}$ and prevent any student involvement in political initiatives (Gille-Belova 2015). As the Ministry actively used its right to control and check HEI performance, it became more difficult to obtain or renew accreditations as well as to secure compulsory official approval for programmes and specialisations. The election of rectors was replaced by Ministry of Education or presidential appointment, so that by the end of the 2000s the Belarusian HE system experienced a significant lack of academic freedom and university autonomy (IBK 2013, 2014).

During the 2000s, the number of private HEIs declined, some because they failed to renew their accreditation with the Ministry of Education. ${ }^{21}$ The number of public HEIs, in contrast, increased to 46 . New public 
HEIs were opened by the state following two distinct trends. The first trend aimed to create public specialised non-university HEIs subordinated to various ministries and state agencies by changing the names of some colleges. Such "relabelling" was necessary for the government to raise the status of the colleges, because there has been almost no demand for special secondary education diplomas since the 1990s. These institutions were directly oriented to the preparation of cadres for a particular public administration sector (army, police, frontier guards) or economic branch (aviation, transportation). The second trend reflected the logic of encouraging regional development by creating small state universities in new places, as was the case with Baranovitchskiï university in 2004 and Polesskiï university in 2006, universities founded in the small cities of Baranovitchi and Pinsk. In both cases, the creation of new establishments responded mainly to demands from a particular ministry or regional authority and increased horizontal differentiation.

There were no foreign HEI campuses in Belarus, except two Russian HEI branches founded as official cooperation projects between the two countries within the framework of the Union of Belarus and Russia. Unlike the Baltic states, where the dominant language of instruction is Russian in all HEIs, there is no student differentiation by language (Belarusian is used primarily in faculties of Belarusian philology). The number of local branches of Belarusian national HEIs remained quite small in comparison with other post-Soviet countries. Only five branches of four public HEIs from Minsk were established: two in provincial cities, and three in the regional centres. However, like in Russia (Kuzminov et al. 2013, 33), these branches are specialised in economics, management and humanities, offering their educational services to students paying tuition fees. On the one hand, this adaptive strategy helped HEIs adjust to the conditions of restrictive state finances; on the other, the same strategy made higher education available for those living in small towns without time and money to spend on regular studies in regional centres or in the capital. Overall, branches became a new dimension of vertical differentiation.

Another important factor for $\mathrm{HE}$ diversification was strong social demand for higher education diplomas and high social expectations for the emergence of new occupations due to the transition to the market economy. The main rationale behind this social demand was the public opinion that a higher education diploma is necessary for career and life success. Most Belarusians were influenced by expectations of economic change and believed that the state-owned Belarusian economy might be 
progressively transformed following the pattern of Western post-industrial countries. This phenomenon explains why the most demanded professions since the 1990s have been lawyers, economists and managers. Official national statistics show that more than $40 \%$ of students study economics, law and management (see Fig. 5.3); while in public HEIs this proportion is about $30 \%$, in private HEIs it is about $80 \%$. Engineering studies ("sciences" and "technology") offered by public HEIs attract only $20 \%$ of students. Compared to the end of the Soviet period, the proportion of students in various fields of study has changed dramatically: in the $1990 / 1991$ academic year, students in "industry" represented almost $50 \%$ and in "economics" only $13 \%$.

However, these social expectations based on anticipated future changes in the structure of the economy did not match the reality. Belarusian authorities did not put in place any liberal economic reforms recommended by international financial organisations, in particular the IMF. The number of employees in the private sector grew in Belarus from $10 \%$ in 1994 to almost $50 \%$ in 2010, but the share of the private sector in GDP reached only $30 \%$ in 2010 , which was at least two times lower than in other post-Soviet states (OECD 2011,34). Almost $80 \%$ of the industrial and agriculture sectors remained public, dominated by state collective farms. The situation differs mainly in the service sector, which contains a large proportion of private enterprises. By the end of the 2000s, Belarusian authorities were forced to publicly recognise the problems connected with the fast growth of the HE system and admit the distortion between HE system output and the real needs of the Belarusian economy, which was unable to absorb such a high number of HE graduates; this was especially true in economics, law and management fields. At the same time, the growing number of persons with $\mathrm{HE}$ diplomas, which reached 467 per 10,000 at its highest level in 2011, was officially interpreted as an important indicator of strong socio-economic development, placing Belarus as a most developed country (MORB 2013a). However, this situation also raises the question of higher education quality, as many employers complain about the low level of graduate competencies and qualifications (Titarenko 2014).

The Belarusian state continues to play a main role in the structuring and functioning of the labour market, which implies maintaining a high level of employment and a low level of salary differentiation (Morgunova $2010,100)$. A survey conducted by the Belarusian Institute for Strategic Studies in 2013 confirmed that a higher level of education does not 
134 O. GILLE-BELOVA AND L. TITARENKO

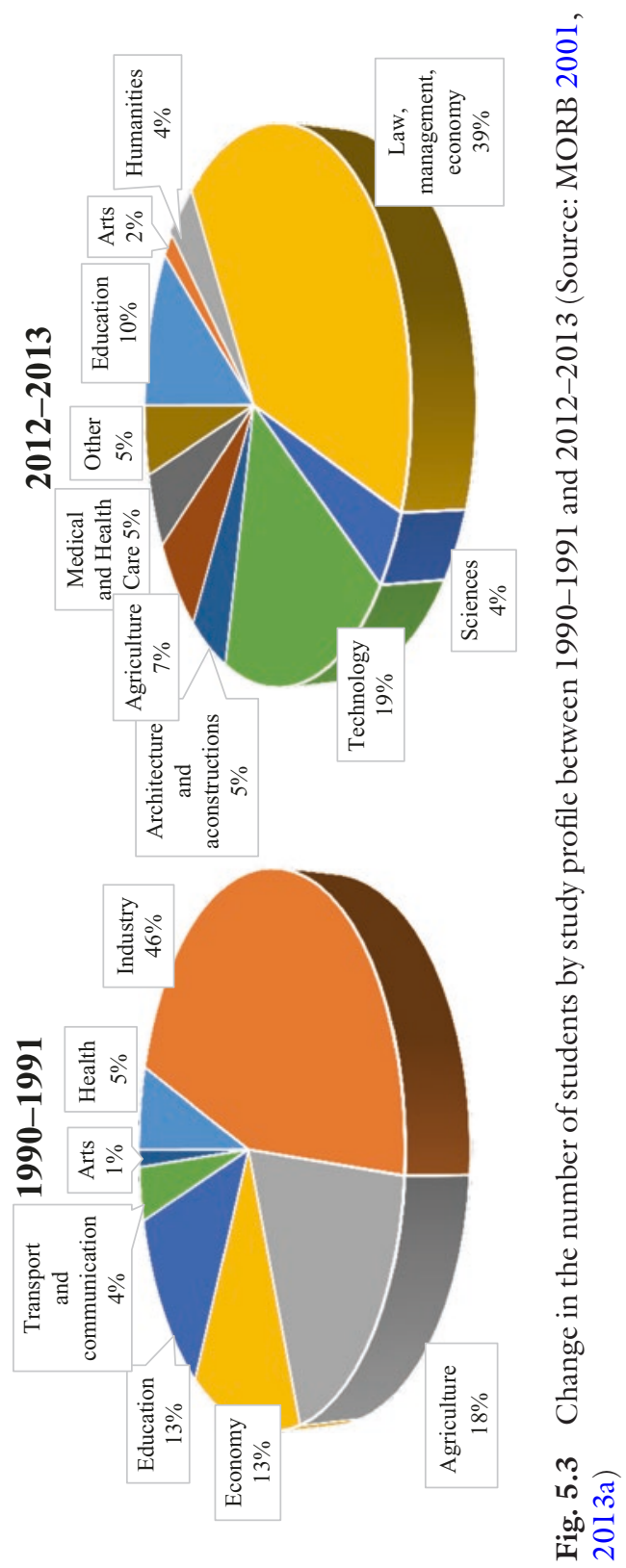


produce a higher salary level for HEI graduates (Chubrik and Shimanovitch 2013). Under these conditions, HE diplomas cannot be converted into material values: persons with high school certificates could theoretically obtain almost the same salary while occupying low-qualified positions in the market, and there is no rational economic motivation to pursue HE diplomas (Sysoev 2010). Thus, the demand for HE could still be explained by social prestige, already important in the Soviet period, that seems to have become almost a social norm in contemporary Belarus.

While the social demand for HE still remains high in Belarus, the demographic situation has dramatically changed: from 2011 to 2012 , the number of secondary school graduates decreased due to a low birth rate in the 1990s. The official government strategy for attracting foreign students could hardly compensate for the inevitable reduction in fees following the decrease in the number of potential students. These demographic and financial problems could have an important impact on the Belarusian HE system by increasing the competition between HEIs for students and financial resources. Some HEIs have better chances in this competition as they have better positions in terms of Belarusian HE vertical differentiation. This factor will be examined in the following.

\section{The HE Institutional Landscape in Contemporary BELARUS}

The typology proposed below defines six types of HEIs (see Table 5.2) and takes into account a variety of criteria regarding HEI educational, research and international activities (some of the criteria are presented in Table 5.3). The empirical data were gathered from official statistics on affiliation and number of HEIs, as well as size including number of faculties, number and characteristics of students (by study profile, level, CT admission score) and teaching staff (by age and scientific degree). As it is difficult to evaluate research activities (for the reasons mentioned above), we took into account the number of $\mathrm{PhD}$ students (aspiranty and doctoranty), the number of $\mathrm{PhD}$ Commissions, ${ }^{22}$ the number of publications (if available) and the number of research centres and research projects (if available $\left.{ }^{23}\right)$. As for the level of internationalisation, we used official data on the number of foreign students and number of international cooperation agreements. We also took into account different official labels such as "leading" HEI status, ${ }^{24}$ as well as the results of national official ratings 


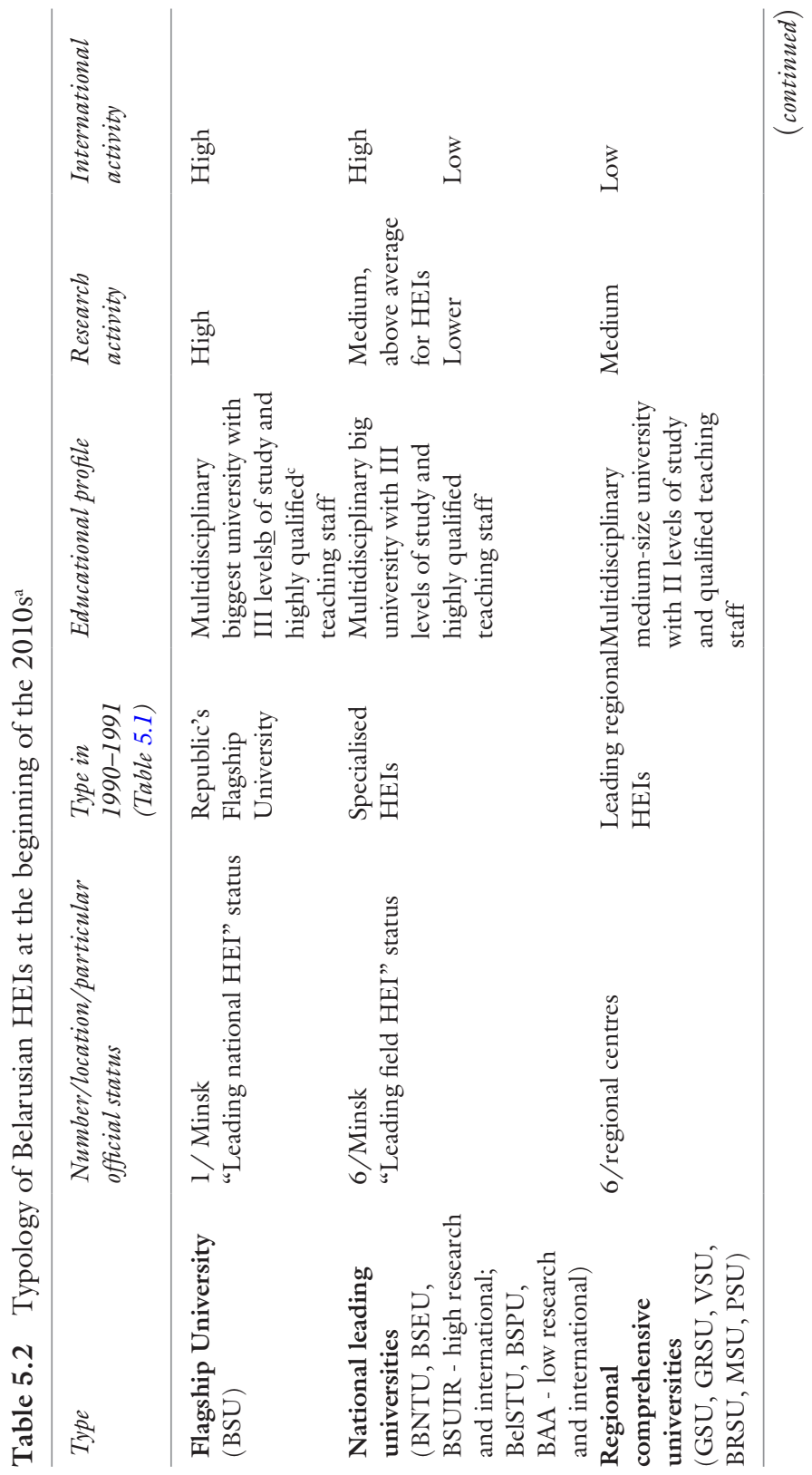




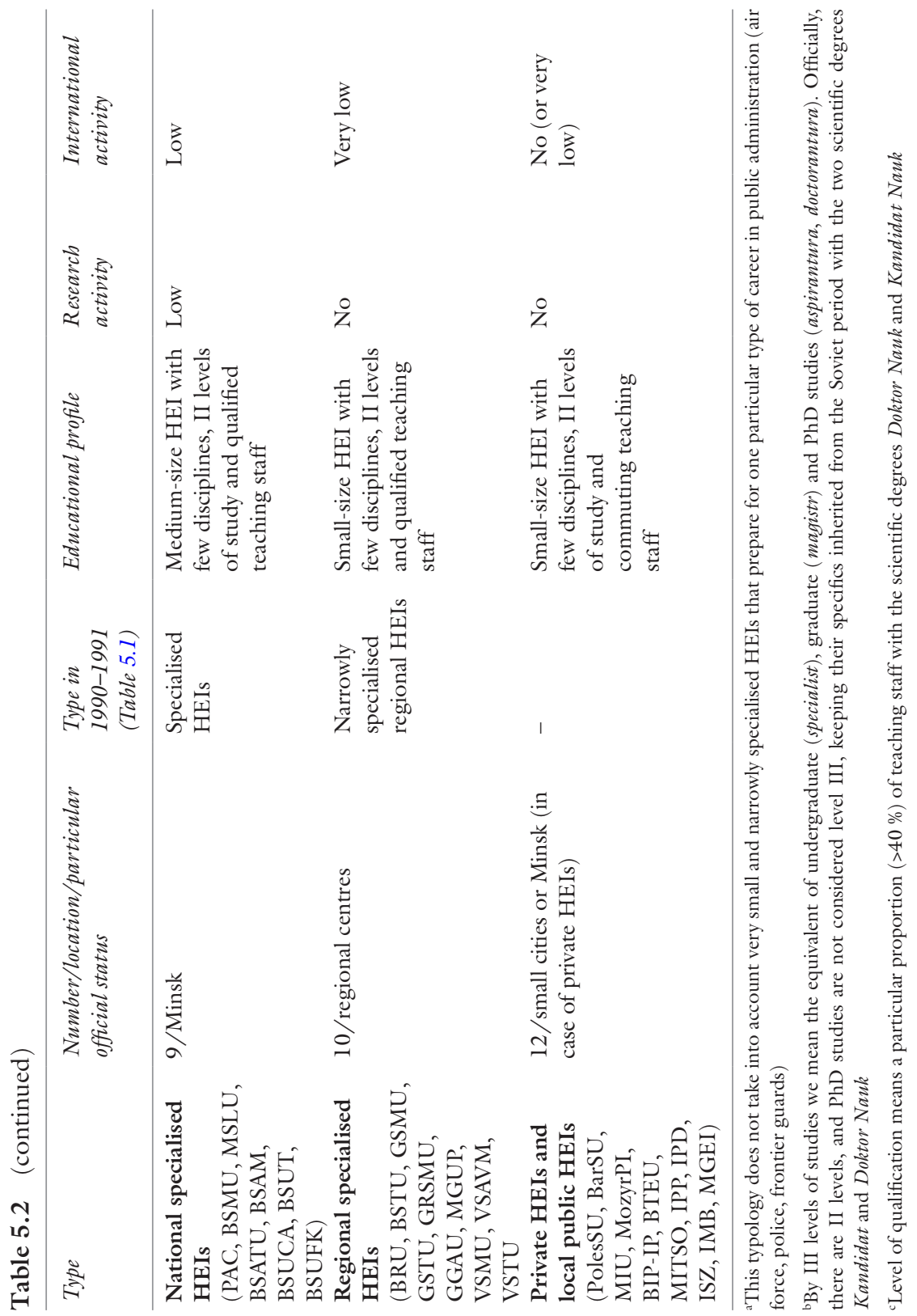




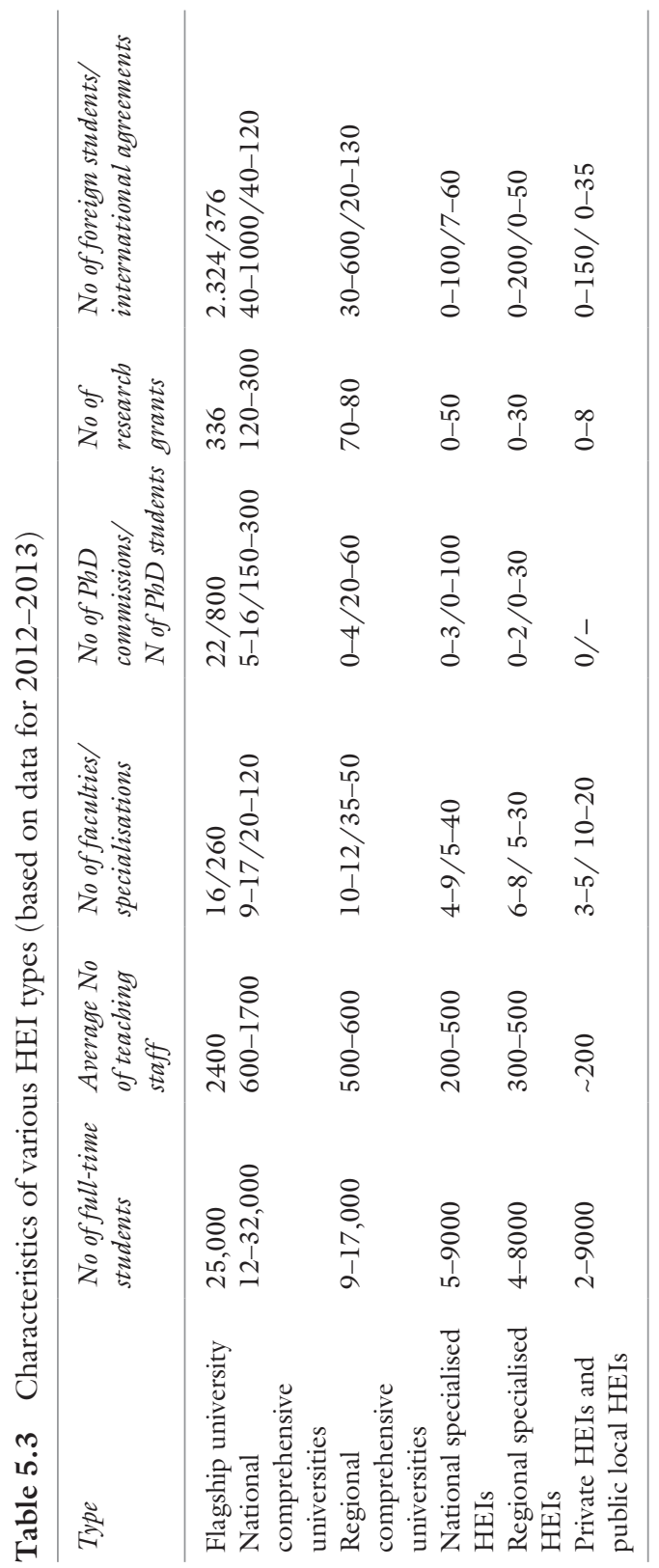


introduced by the Ministry of Education in Belarus in 2013 as well as various international ratings, even if very few Belarusian HEIs figure into them (mainly BSU, BNTU, BSUIR).

BSU maintains its status as the leading national university in Belarus and the only one that can be qualified as a "research university". It has a significant size with 25 thousand students enrolled in more than 260 various programmes (spetsializatsii) offered by 16 faculties and 4 institutes. The staff has a very high level of qualification, more than $50 \%$ with $\mathrm{PhD}$ degrees. The enrolment process is competitive, and BSU graduates can usually obtain employment with relative ease. BSU trains cadres for teaching and research in the sciences and humanities as well as for Belarusian public administration and the private sector. There are several research institutions belonging to BSU where students can gain research experience in parallel to their regular studies. BSU counts the largest number of PhD students (almost 800) and $\mathrm{PhD}$ Commissions (22), and confirms its leading position in the national system through both SCOPUS publication ranking and a high number of research grants. Several research institutions that belong to BSU have the highest national rankings in publications as well. ${ }^{25} \mathrm{BSU}$ has the highest number of international cooperation agreements and a significant proportion of foreign students (10\%). In comparison to other Belarusian HEIs, BSU occupies the best positions in various international rankings. ${ }^{26}$

A second group of "national comprehensive universities" is composed of six HEIs belonging to the "national specialised HEIs" group. These have managed their internal diversification and generally have a significant size: the smallest is Belarusian State Technological University (BelSTU) with 12,000 students and more than 600 teaching staff, and the biggest is BNTU with more than 32,000 students and more than 1,700 teaching staff (more than $40 \%$ with scientific degrees). They have many faculties (from 9 to 17) with a high number of specialties varying from 20 at BAA to 121 at BNTU, and all of them host 150-300 $\mathrm{PhD}$ students and at least $5 \mathrm{PhD}$ Committees. There are two sub-groups inside this category of "national universities": HEIs from the first sub-group (BNTU, BSEU, BSUIR) differ within the group by higher research levels and international activity; they attract students with high CT scores in their fields and have high positions in ministry ranks, sometimes even in regional and international rankings. These HEIs have "leading field" status and create programmes and manuals for corresponding disciplines.

The third group of "regional comprehensive universities" includes the six HEIs (former "leading regional HEIs") situated in regional centres. Two were transformed into universities in the 1970s (in Gomel and Grodno) and currently demonstrate a higher level of performance than 
the three (Vitebsk, Brest, Mogilev) that were relabelled as universities from pedagogical institutes in the 1990s. Only one, Polotsk State University (PSU), was founded in 1968 to serve the urgent needs of the country (USSR) in terms of new cadres of engineers for the chemical industry in the city of Novo-Polotsk; it was transformed into a university in 1993. They differ in size depending on the size of the region in which they operate and usually have 9-12,000 students enrolled in 10-12 faculties offering 35-50 specialties with 500-600 teaching staff (up to $40 \%$ with scientific degrees). ${ }^{27}$ They are almost totally oriented to the preparation of new teachers for all branches of education (pre-school, primary and middle school, high school). As they are no longer called "pedagogical", they established new programmes to attract talented ambitious students from their regions with new specialisations. However, overall enrolment is still a challenge as young people are free to decide whether they want to study in regional universities, in the capital, or abroad. Their research activity is generally low with some $\mathrm{PhD}$ students in a few fields; only Grodno and Gomel SU have their own PhD Commissions. Some host a low number of foreign students and conduct some international cooperation projects.

The next group of "national specialised HEIs" includes nine HEIs situated in the capital city of Minsk with variable size from 1000 students at the smallest, the University of Arts and Culture (BSUCA) and the Academy of Music (BSAM), to 11,000 at the technical-agrarian university Belarusian State Agrarian Technical University (BSATU); overall enrolment generally varies between 5000 and 9000 students. The number of teaching staff varies from 200 to 500 with the exception of MSLU university of foreign languages $(\sim 800)$ and medical BSMU $(\sim 1,100)$. The proportion of staff with scientific degrees is around $30-40 \%$ with some exceptions. The number of faculties varies from four to nine and reflects the disciplinary specialisation of these HEIs. Despite the diversification of their programmes (from 5 to 40 specialisations), the majority of students are enrolled in major specialised profiles (medicine, foreign languages, art and culture, agriculture) and their main mission is to prepare specialists for the national labour market. Most do not host PhD students and only a few foreign students (with the exception of MSLU and Belarusian State Medical University (BSMU)).

The group of "regional specialised HEIs" is quite similar to the previous group but includes HEIs situated outside the capital, mainly in regional centres which already have regional universities. These HEIs are smaller in size with 4,000-8,000 students (except Brest technological Belarusian State Agrarian Technical University (BSTU) with 11,000 students), 300-500 teaching staff, $6-8$ faculties and up to 30 specialisations. 
If they are specialised in the same field as their "mother" national specialised HEIs, they are much less competitive and serve mostly regional needs (industries or particular plants/factories).

The last group is heterogeneous and includes nine private HEIs, two newly established public local universities and one pedagogical institute. They are generally small-sized with 2,000 to 9,000 students and 50-300 teaching staff, $30-40 \%$ with scientific degrees. Private HEIs generally have 3-5 faculties with 10-20 specialties offering popular courses in management, economics and law, and provide educational service for almost anyone who can pay the tuition fee. Most do not have foreign students with few, if any, international cooperation agreements. Their major role is to provide diplomas and socialisation for the students, but their graduates generally have difficulty finding proper employment. This means that they are oriented only to receiving the diploma "paper" (korotchki) rather than acquiring professional knowledge and competences. As for the three public local HEIs, they are situated in relatively small cities and were opened in the 2000s to meet the demand of local authorities as well as to keep the provincial youth "in place" and to forestal that they move to regional centres or the capital to study. This always results in inter-regional youth migration with low chances of return after graduating. The "new local universities" do not have enough resources to attract qualified staff, but have good enrolment. The staff often commutes between these universities and the nearest regional universities, where most qualified staff are also employed.

The increasing number of HEIs and offered specialisations led to a higher horizontal diversification of the Belarusian HE system during the 1990s and early 2000s, but it kept the main patterns of differentiation inherited from the Soviet period. The leading state HEIs reinforced their positions at the beginning of the 1990s, while the private or recently created states HEIs have played a marginal role in the national HE system. Vertical differentiation increased: a few leading HEIs have the highest passing scores in the country, and the rest accept almost all enrolees (Dopnabor 2016).

\section{Conclusion}

If $\mathrm{HE}$ diversification in Western Europe was a failed attempt to deflect students from the elite university sector into the non-university sector during massification (Neave 2000,12), the issue of diversification was much different in Belarus. The nature of the massification process was also different: it was not "the product of state intervention" following economic demand for a more qualified workforce like in Western countries, but 
rather a more spontaneous process in which the state abandoned "its monopoly on demand in higher education" and could not "fully control the supply side" (Froumin et al. 2014, 209). During the massification of Belarusian HE, new HEIs were opened and the existing ones tried to diversify their curricula, principally in response to social demand based on expectations of labour market changes as an outcome of economic reforms. Many HEIs used this situation as a chance to step away from the narrow specialisation imposed during the Soviet period.

The Belarusian authorities did not have a blueprint or particular design for the new HE system; they followed a process of spontaneous diversification during the 1990s, contributing more actively during the 2000 s with the creation of new public HEIs in response to ministerial or regional authority demands. The expansion of the Belarusian HE system and its horizontal diversification were largely financed by students and their families. However, they became neither new stakeholders nor employers and had almost no influence on the main issues related to education. The Belarusian government remained the key stakeholder, reinforcing its control over the HE system since the 2000s, mainly for political reasons, and despite its incapacity to efficiently connect the HE system to labour market needs.

Regarding prospects for the development of the Belarusian HE system, it had already reached the limits of its expansion by the end of the 2000s, and it is likely that reductions will be reinforced in the near future. The decreasing number of national students and limited strategy results for exporting Belarusian HE services abroad will inevitably influence the number of HEIs. The Ministry of Education has already announced a new aim to cut the number of HEIs by $2020-2022$, officially motivated by a desire to align with international standards (BELTA 2015). It is thus logical to expect the absorption of smaller state HEIs by the bigger regional or national institutions as well as the disappearance of some private HEIs. The number of study profiles at HEIs is likely to shrink, while their specialisations are likely to increase. As a result, the Belarusian state will strengthen its role as the main actor in remodelling the HE system; it will likely try to assign a particular role to every HEI and increase differentiation, so that few institutions will be able to compete on the international or even the regional level, while other institutions will respond to specific national and regional needs. 


\section{Notes}

1. For the Soviet period we use "Byelorussian" and for the post-Soviet period "Belarusian" in accordance with the official name change: from the Byelorussian SSR to the Republic of Belarus in 1991.

2. For a detailed description of the general design of the Soviet "master plan" and its application in the Russian context, see Kuzminov et al. 2013, 14-26; Froumin et al. 2014.

3. Its own academic staff came mainly from Moscow, Kiev and Kazan Universities.

4. Belarusian State Medical University (BSMU). Most HEIs changed names in 1990 and their new (formal English) names used later in the text will be mentioned in the footnotes in the first part of this chapter.

5. Belarusian State Pedagogical University (BSPU).

6. Belarusian State Economic University (BSEU).

7. Belarusian National Technical University (BNTU).

8. Minsk State Linguistic University (MSLU).

9. Belarusian State University of Culture and Arts (BSUCA).

10. Belarusian State University of Informatics and Radioelectronics (BSUIR).

11. Belarusian State Agrarian Technical University (BSATU).

12. Belarusian State Technological University (BSTU).

13. Belarusian-Russian University (BRU).

14. Belarusian State University of Transports (BelSUT).

15. Vitebsk State Technological University (VSTU).

16. Grodno State Medical University (GSMU).

17. It was not replaced until 2007 by the new Law on Higher Education, which in turn was replaced in 2011 by the new Code on Education.

18. At the beginning of 2010 , the fees varied from 600 to $1200 €$ per year depending on the HEI and the type of studies.

19. In mid-1990 this proportion was about $35 \%$ in both private and public sectors.

20. In the latter case, students do not pay for their studies but should work for two years in a state-appointed workplace upon graduation. This practice, called raspredelenie, is inherited from the Soviet period.

21. The most famous example was European Humanities University (EHU), one of the rare private universities created in 1994 and financed mainly by international organisations, foreign governments and foundations. It was forced to close in Belarus in 2002 and moved to neighbouring Lithuania where it continued to teach Belarusian students via distance-learning programmes before reorienting its strategy in recent years, during which EHU has started to attract Russian-speaking students from the Baltic countries. 
22. The PhD Commission (dissertatsionnyi komitet) is the official body in charge of granting the $\mathrm{PhD}$ degree in a particular discipline.

23. We assume that the number of projects shows that some HEIs are more active in the search for projects than others, even if this number does not directly reflect the scientific potential of the HEI.

24. The Code on Education (art. 209) introduced official differentiation inside the HE system through the creation of "leading" (vedushtshii) status "in the HE system", or "in a particular field of HE", accorded to two and six HEIs, respectively.

25. One such research institution, the Institute of Physics-Chemistry Problems, has the highest rating on the $\mathrm{H}$-index in Belarus.

26. According to QS World University Rankings, BSU is placed between 491 and 500; according to EECA 2014/2015, BSU is in the top 50 for the region with the 38 th position; according to the Russian ranking EXPERT RA, BSU belongs to class B (as do most of the best HEIs from other CIS countries). According to Webometrics Ranking of World Universities in 2014, BSU took position 612 and was in place 1461 according to Scimago Institutions Rankings (data source: SCOPUS publication numbers).

27. The exception is Grodno SU with more than 17,000 students and almost 1000 teaching staff as well as 13 faculties with 90 specialisations, 600 foreign students, 131 international cooperation agreements, almost 130 research projects and $180 \mathrm{PhD}$ students. Polotsk SU is also slightly bigger $(\sim 15,000$ students $)$ than other regional universities.

\section{REFERENCES}

BELTA (Belarusian Telegraph Agency). 2015. Tchislo Belorusskih vuzov sokratitsja s 54 do 20 [Number of Belarusian Institutions of Higher Education will be reduced from 54 to 20], February 26. Accessed 5 Oct 2015. https://news.mail. $\mathrm{ru} /$ inworld/belarus/society/21204616/? frommail=1

Chubrik, A. and G. Shimanovitch. 2013. Otdacha na obrazovanie i otsenka chelovecheskogo kapitala $v$ Belarusi [Return from Education and Evaluation of Human Capital in Belarus]. Report SA\#03/2013. http://www.belinstitute. eu/sites/biss.../BISS_SA03_2013ru_2.pdf

Dopnabor ne pomog: v belorusskih vuzah ostalis svobodnie mesta. 2016. [Additional Set did not help: There are Vacant Places in Belarusian Universities]. August, 10. Accessed 11 Aug 2016. https://news.mail.ru/society/26725125 $/$ ?frommail=1

Education Code of Republic of Belarus. 2011. [Kodeks Respubliki Belarus' ob obrazovanii] № 243-3, Retrieved April 20, 2012. http://www.pravo.by/main. aspx? guid $=3871 \& \mathrm{p} 0=\mathrm{Hk} 1100243 \& \mathrm{xp} 2=\{\mathrm{NRPA}\}$ 
Froumin I., Y. Kouzminov, and D. Semyonov. 2014. Institutional Diversity in Russian Higher Education: Revolutions and Evolution. European Journal of Higher Education. Published Online 09 June 2014, 209-234. http://dx.doi. org/10.1080/21568235.2014.916532

Gille-Belova, O. 2014. "Les réformes de l'enseignement supérieur en Biélorussie: entre poids de l'héritage soviétique et influence internationale diffuse" [The Reforms of Higher Education in Belarus: Between the Weight of Soviet Heritage and Diffuse International Influence]. Revue d'études comparatives EstOuest 45 (1): 55-90.

- 2015. Beyond the Limits of the European Higher Education Area: The Case of Belarus. European Journal of Higher Education 5 (1): 83-95. http://dx.doi.org/ 10.1080/21568235.2014.979848.

Huisman, J., V.L. Meek, and F.Q. Wood. 2007. Institutional Diversity in Higher Education: A Cross-National and Longitudinal Analysis. Higher Education Quarterly 61 (4): 563-577.

IBK [Independent Bologna Committee]. 2013. White Book. Reforming of the Belarusian Higher School in Accordance with the Aims, Values and Main Directions of the European Higher Education Area policy. Minsk: IBK. Accessed 16 July 2013. http://bolognaby.org/?p=878\&lang=en

- 2014. Alternative Report. Belarussian Higher Education: Readiness to EHEA Admission. Minsk: IBK. Accessed 12 Dec 2014. http://bolognaby. org $/$ p $=1872$ \&lang=en

Krasovskiï, N.I. 1972. Vysshaja shkola sovetskoï Belorussii [The Higher Education in the Soviet Bielorussia]. Minsk: Vysheïshaja Shkola.

Kuzminov, Y., D. Semyonov, and I. Froumin. 2013. "Struktura vuzovskoï seti: ot sovetskogo k rossiïkomu masterplanu" [HEIs Network Structure: From Soviet to Russian Masterplan]. Voprosy obrazovania 4: 8-63.

MORB [Ministry of Education of the Republic of Belarus]. 2001. Ustanovy vysheïshai adukatsii Respubliki Belarus' na pachatak 2001/2002 navuchal'naga goda. Statystychny davednik [The HEIs of the Republic Belarus at the Beginning of the 2001/2002 Year. Statistics]. Minsk: Galouny infarmatsiina-analitychny tsentr Ministerstva adukatsii Respubliki Belarus'.

- 2013a. Belorusskoe obrazovanie v kontekste mezdunarodnyh pokazatelei [Belarussian Education in the Context of International Indicators]. Minsk: Ministerstvo obrazovanija.

- 2013b. Ustanovy pysheïshai adukatsii Respubliki Belarus' na pachatak 2013/2014 navuchal'naga goda. Statystychny davednik [The HEIs of the Republic Belarus at the Beginning of the 2013/2014 Year. Statistics]. Minsk: Galouny infarmatsiïna-analitychny tsentr Ministerstva adukatsii Respubliki Belarus'.

Morgunova, A. 2010. "Zanjatost' v Belarusi: politika i povsednevnost" [The Employment in Belarus: Policies and Realities]. Vestnik obchtshestvennogomnenija 4 (106): 98-115. 
Narodnoe hozjaystvo Respubliki Belarus v 1991 godu [The National Economy of the Republic Belarus in 1991], ed. L. Sasnouski, D. Vasilenka. 1993. Minsk: "Belarus" publishing house.

NSCRB [National Statistical Committee of the Republic Belarus]. 2013, 2014, 2015. Obrazovanie v Respublike Belarus. Statisticheskii sbornik [The Education in the Republic Belarus. Statistics]. Minsk: NSCRB.

OECD. 2011. Competitiveness and Private Sector Development. Eastern Europe and Southern Caucasus 2011. Competitiveness Outlook. OECD Publishing. http://dx.doi.org/10.1787/9789264112322-en.

Silova, I. 2009. Varieties of Educational Transformation: The Post-Socialist States of Central/South Eastern Europe and the Former Soviet Union. In International Handbook of Comparative Education, ed. R. Cowen and A.M. Kazamias, 295-320. Dordrecht: Springer.

Sysoev, S.A. 2010. "Institutsional'nye osobennosti investitsiï v chelovecheskiï kapital v Respublike Belarus"' [The Institutional Particularities of the Human Capital's Investements in the Republic of Belarus]. Zhurnal institutsional'nyh issledovaniï 2 (2): 109-117.

Teichler, U. 1988. Changing Patterns of the Higher Education System. London: Jessica Kingsley.

Titarenko, L. 2014. "Novye i starye problemy kachestva obrazovania v Belarusi" [New and Old Problems of Education Quality in Belarus]. Sociologia 2: 104-112.

Vetokhin, S. 2001. Reformirovanie vysshego obrazovanija v Respublike Belarus' [The Reforms of the Higher Education in the Republic of Belarus]. Minsk: RIVSh/BGU.

Yearbook of Big Soviet Encyclopedia, ed. L. Shaumjan. 1959. Moscow: Big Soviet Encyclopedia.

Olga Gille-Belova, $\mathrm{PhD}$ in Political Science, Professor in Russian Studies at University Bordeaux Montaigne (France) and researcher at the Center for Studies of Modern and Contemporary History (CEMMC). She is the author of publications on the politics and foreign relations in post-Soviet countries, and recently on emigration and higher education policies.

Larissa Titarenko, Dr. Hab in Sociology, Professor at the Department of Sociology at Belarusian State University (Minsk, Belarus). She is the author of numerous publications on history of social thought, education, youth and gender studies, urban sociology and political sociology. 
Open Access This chapter is distributed under the terms of the Creative Commons Attribution 4.0 International License (http://creativecommons.org/licenses/ by $/ 4.0 /)$, which permits use, duplication, adaptation, distribution and reproduction in any medium or format, as long as you give appropriate credit to the original author(s) and the source, provide a link to the Creative Commons license and indicate if changes were made.

The images or other third party material in this chapter are included in the chapter's Creative Commons license, unless indicated otherwise in a credit line to the material. If material is not included in the chapter's Creative Commons license and your intended use is not permitted by statutory regulation or exceeds the permitted use, you will need to obtain permission directly from the copyright holder.

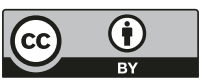

